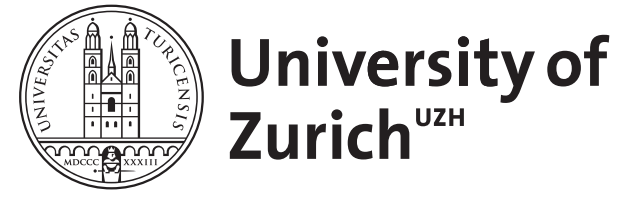
Archive

University of Zurich

University Library

Strickhofstrasse 39

CH-8057 Zurich

www.zora.uzh.ch

Year: 1958

\title{
Recollections of a Former Leipzig Student
}

Ackerknecht, Erwin H

DOI: https://doi.org/10.1093/jhmas/xiii.2.147

Posted at the Zurich Open Repository and Archive, University of Zurich

ZORA URL: https://doi.org/10.5167/uzh-155157

Journal Article

Published Version

Originally published at:

Ackerknecht, Erwin H (1958). Recollections of a Former Leipzig Student. Journal of the History of Medicine and Allied Sciences, XIII(2):147-150.

DOI: https://doi.org/10.1093/jhmas/xiii.2.147 


\title{
Recollections of a Former Leipzig Student
}

\author{
ERWIN H. ACKERKNECHT*
}

T $T$ was rather reluctantly, almost thirty years ago, in my eighth 1 semester, that I became one of the more than sixty members of Professor Sigerist's famous Institute of the History of Medicine at Leipzig. Becoming a member meant that I not only participated in the courses, seminars, and social events of the Institute, but that I received a key, a work table, and a thesis subject. The majority of the members were medical students, a little more than one-tenth of the total medical student body; the rest were young doctors and some nonmedical people. Having always been very much interested in history, I had taken a course in medical history in my second semester with a very famous, very learned, and very dull medical historian. Thereafter I felt that this first contact with medical history had also been my last. But my friends and classmates who had persuaded me to join the Institute were right. The professor was really an unusual man, the Institute was really a most stimulating place, and medical history could really be something much better than the dusty subject with which I had first been confronted.

The professor was very different from most professors I had ever seen. He was not only polite, he was also gay and friendly. He completely lacked the stiffness or arrogance which was apparently an indispensable element of the dignity of most of his colleagues. We were not unhappy that he had replaced Geheimrat Sudhoff, who would still "thunder" occasionally around the Institute (Geheimräte didn't yell, they thundered). Professor Sigerist was surprisingly elegant in his dress, manners, gestures, in his speech and writing. He was extremely brilliant, many-sided and open-minded; in class and privately he competently discussed an incredible variety of subjects and ideas without ever being dogmatic. Though I sometimes almost regretted that my teacher wasn't firmer, I probably liked best in him that he never tried to impose his opinion on anybody and let everybody find his own way. The only thing he insisted upon was quality.

At that time we searched honestly for solutions to what seemed to us professionally and generally a very complex, difficult, and

- Director, Institute of the History of Medicine, and Professor, University of Zürich, Switzerland. 
dangerous situation, and we had the feeling that he was searching with us. He was not only chronologically young; he was also young in thought and feeling. His enthusiasm for life and his science was contagious. Most of us had grown up in midst of a world war, famine, civil war, and inflation, and were not particularly addicted to optimism. But we found it extremely refreshing that this lucky man from Switzerland, who had never experienced any of these 'blessings' of our times, could be so optimistic.

The Institute was a beehive in the best sense of the word. There was an abundance of courses (introductory, special subjects) , seminars, and colloquia. The "colloquia" were actually lectures given either by Institute members or more often by nationally prominent figures in medicine or the social sciences. We were addressed, for example, by Brugsch, Grotjahn, Liek, Meyer-Gross, and also by Ed. Heymann or the Federal Attorney General Ebermaier, in series of lectures which centered around such subjects as "The Doctor and Government," or "The foundation and goals of contemporary medicine," and which were later published as books. About a dozen such men would thus come to the Institute during the year.

There were people from other departments collaborating in the Institute, among them physiologists or pathologists, and several philosophically minded sociologists. The Institute would provide a tribune for some (at the time) very unorthodox approaches such as psychoanalysis or von Weizsäcker's philosophical "anthropology." There was a stream of famous foreign visitors like Welch, Barker, Evans, or Duhamel, whom, it is true, we would in general only see from a distance, if at all. Younger scholars worked temporarily in the Institute, like d'Irsay, Walter Pagel, Bilikiewicz, or Claudius Mayer, also older ones like Prinzhorn or the widow of Celli. There were such excellent assistants as E. Hirschfeld or $O$. Temkin to whom we would generally turn with problems arising from our work, because the professor was very busy and with all his cordiality he remained at a certain distance. (It was later on my great privilege to cross that line and to become Henry's personal friend. Yet I am trying here not to project later experiences into this picture, but to describe things as I saw them at the time.) There was also the dear "Oberinstitutsgehilfe" Robert Richter, who would so ably take care of all technical problems.

And there was the mass of members, the infantry-students preparing seminar papers or doctoral theses; among these there were 
always some foreigners (Arabs, Greeks, Bulgarians, Japanese). The largest column, in consequence of the Institute's traditions and the director's own early interests, was made up of those working on medieval medical manuscripts. But they were not the most characteristic group. The most valued band were the "philosophers" who searched Hippocrates, Paracelsus, or the Romantics. There were also platoons delving into the history of diseases or the history of drugs. There was no work yet in social medicine or the sociology of medicine, unless one wants to force my thesis on the medical reform movement of 1848 into this pigeon-hole.

It is a miracle that all these people ever fitted physically into the few rather poorly furnished rooms in the Talstrasse. However, the director accomplished not only this, but an even greater miracle: all these people, so different in background, outlook, and activities nevertheless developed an esprit de corps by working and living together, and eventually somehow belonged together. Sigerist was right when he described his Institute as the "Institute of the Kyklos group" (Kyklos was the name of the yearbook he founded in Leipzig) in comparing it with the Institute of Sudhoff, as fitting exclusively his own personality. Such a group actually existed, and its creation was perhaps Sigerist's greatest achievement in Leipzig.

To the Leipzig medical student and young doctor of the late 1920's and early 1930's this amazingly well-organised Institute was an oasis in spite of its difficulties, which it did not lack either. Nobody had ever believed in or much profited from the three years of artificial prosperity (1926-1929), based on American loans. And then came the abyss of the depression, deeper in Germany than anywhere else, mirrored queerly, but unforgettably in the Brecht-Weil "Threepenny Opera." In this general environment the "Seminarzimmer" generously offered dozens of new journals and books for the study of problems of contemporary medicine, thought, and society, a quiet place to discuss them (passionately perhaps, but politely) and cigarettes with the famous Institute seal to smoke while doing so. Needed books came easily to the "Doktorandenzimmer," due to the excellent organisation of the whole. Writing there, one was confident that the work, when good, would be published in one of the numerous Institute outlets. We worked hard and quite "professionally," but with the feeling that this was not an end in itself but would lead us to insights beyond our specialty. It was with pride that we listened to 
or read the newest ideas of our professor, with whiclı he seemed to overflow (also on organisational matters), particularly in his two books which appeared then, Man and Medicine and The Great Doctors, but also in such outstanding papers as "Kultur und Krankheit," "William Harvey's Stellung in der europäischen Geistesgeschichte," "Wandlungen des Konstitutionsbegriffs," "Das Bild des Menschen in der modernen Medizin," "Probleme der medizinischen Historiographie," and "Psychopathologie und Kulturwissenschaft." It was with joy that we greeted the wonderful parties which the professor organised. In the summer of 1929 he even took twelve members of the Institute with him to the International Congress of Medical History at Budapest.

Looking back at the work of Sigerist and the Kyklos group in Leipzig, it appears today as part and parcel of that short period in German history called the "Weimar Republic" and honored by the late German dictator with the label of "fifteen years of ignominy and shame." Today it seems rather likely that posterity will look at this period, in spite of its political wretchedness and blunders, in spite of its chaotic and fragmentary traits, as one of the most brilliant and fruitful periods of German intellectual history. The books burned, the music and paintings forbidden in 1933 will long be admired. Due to the encounter of this particular general atmosphere and Sigerist's genius, German medical history also had its "Weimar" period. It ended when its creator left for the United States in 1932. He had the strength to build there again, to build bigger and perhaps better things, but with other materials and other tools. They were different, and perhaps never as close to his heart and as full of it as the creations of his youthful Leipzig days. 